\title{
Ecological View at Uyun Layla in Saudi Arabia
}

\author{
Wafaa Mohammed Al-Ghanem ${ }^{1}$
}

\begin{abstract}
This study deals with the change in the biodiversity in Uyun Layla lakes during the last 30 years. The study revealed that the aquatic habitat has been altered to terrestrial dry habitat with complete alteration in the type of vegetation covering this area. The vegetation was scanty, poor halophytic species. Only, twelve perennial species were recorded during the studied period which lasts for four years, from October 2006 till May 2010. Three other species were found in the first two years only, Molkiopsis ciliate, Capparis orientalis and Salicornica fruticosa. From this study, we can conclude that the aquatic habitats in Saudi Arabia are in danger and needs further attention, study and preservation.
\end{abstract}

Keywords: Al-Aflaj lakes-biodiversity-desertificationvegetation study- Uyun Laila

\section{INTRODUCTION}

Climatic change and global warming have greatly affected the ecosystem due to the changes happened in both animal and plant life. Mackey (2007) Predict an interaction between climate change and other drivers of biodiversity that will increase extinction risk from that seen in periods of rapid climate change in the past. Not only territorial ecosystems but also marine ones have changed in response to climatic changes happened. Barange et al. (2010) pointed to the loss of water, dams, chemical pollution and introduced species in rivers, lakes and ponds according to environmental disorders. These may cause, complete corruption, or dryness of the aquatic habitat. Mann and.Lazier (2006) clarified the importance of the aquatic habitats as they recycle nutrients, purify water, attenuate floods, recharge ground water, provide habitats for wildlife, used for human recreation and very important to the tourism industry. For that, we have to preserve the aquatic ecosystem as the stress on an aquatic ecosystem can be a result of physical, chemical or biological alterations of the environment (Davenport, 2008).

In Saudi Arabia, the aquatic habitats are located mainly in the Arab gulf, Red Sea and the internal lakes and ponds. While the aquatic flora, is not strikingly rich. Members of aquatic group can be seen in drainage canals or in shallow stagnant waters of natural seasonal streams or manmade drainage systems. Some of the aquatic species belonging to the flora of Saudi Arabia are cosmopolitan, such as Lemna, Ceratophyllum and
Nymphaea spp., which are introduced into the Kingdom. In most cases, introductions take place accidentally by humans or by visiting migratory birds like water fowl. Meanwhile the pollution happened after the Gulf War caused major disturbance in the marine biota in this area (Asif-Kan and Al-Homaid, 2003). UNEP/PERSGA (1997) announced that the large scale coastal construction projects, in Saudi Arabia, caused significant destruction of marine habitats and marine environment.

'Uyun Layla (also known as Layla Lakes and AlAflaj Lakes) located $10 \mathrm{~km}$ south Layla town in AlRiyadh province was one of the aquatic habitat in Saudi Arabia. It was one of the tourist visits for picnic and enjoys (Photos.1, 2, 3 \&4). A tourist resort has been constructed, though never used, presumably due to the concurrent demise of the lakes. This area was a popular recreational area in the past, given its proximity to Riyadh and al Kharj .

In spite of that, no serious scientific research has been undertaken in this area, except with regard to water abstraction and engineering. For that, the vegetation grown in Uyun Layla has been studied over four years from October 2006 till May 2010 to realize the change happened in the type of vegetation during this period.

\section{I- Studied Area}

The studied area is about 3,000 ha. with an altitude of $540 \mathrm{~m}$, and $330 \mathrm{~km}$ south of Al-Riyadh city. It comprises a total of 23 doline and sinkhole subsidence craters (Photographs 5,6, \& 7), of which five are shaped irregularly, the largest at about 1,500 by $500 \mathrm{~m}$, and the other four ranging in size down to 250 by $75 \mathrm{~m}$. The remainders are circular in shape, of which four measures between 100 and $175 \mathrm{~m}$ in diameter, and four are less than $100 \mathrm{~m}$ in diameter. Thirteen craters are now dry. The lakes are clustered in three main groups, with one outlier at $2.7 \mathrm{~km}$ to the north. Each group is located within saucer-shaped depressions (Photographs 8, 9 \& 10). Additionally, in the past, deposition of fine lime sediments when the lakes used to overflow their rims led to the formation of small convex mounds. The water surfaces lie at different levels in each crater, although the waters of the main lake are connected to all the other lakes and sinkholes. Over-abstraction has caused extreme desiccation of the shallower dolines and

\footnotetext{
${ }^{1}$ Princess Nora University, Faculty of Science, Botany Department Al-Riyadh- Saudi Arabia

Received March 22, 2011, Accepted March29, 2011
} 
sediments forming the crater walls and surrounding terrain.

\section{MATERIALS AND METHODS}

Monthly visits were done to the studied area from October 2006 to May 2010 to record the different plant species grown in this area. No quadrates have been done, but the plant species grown in each doline have been recorded throughout the time of study. Photographs of selected sites have been taken to clarify the changes happened in this area and the vegetation covering it. The different species have been identified and putted in its systematic position in the faculty herbarium for further investigation

\section{RESULTS AND DISCUSSIONS}

Johnson (1997) identified the natural environment as all living and nonliving things occurring naturally on earth and the environment encompass the interactions between them. The rate and efficiency of these interactions termed biodiversity and the consequences resulted from the loss of biodiversity according to climate changes beside the unorganized uses, is one of the major driver in the future (Duraiappah, 2006 andPressey et al., 2007). These changes may cause a complete destruction of the habitats and this is a key role in extension and a cause of desertification (Lopez-Pujol, 2006). 'Uyun Layla (also known as Layla Lakes and AlAflaj Lakes) located $10 \mathrm{~km}$ south Layla town in AlRiyadh province, are a series of small to medium sized limestone karst lakes, unique in the Arabian Peninsula. Formerly the site was well vegetated, but now it is seriously degraded owing to direct abstraction of water for agricultural irrigation. Prior to 1984, the lakes had fringing reed-beds and clumps of Tamarix; tall grasslands of Desmostachya bipinnata covered the surrounding area. The remaining lakes are now almost barren; the continual fall in water level (one cm every

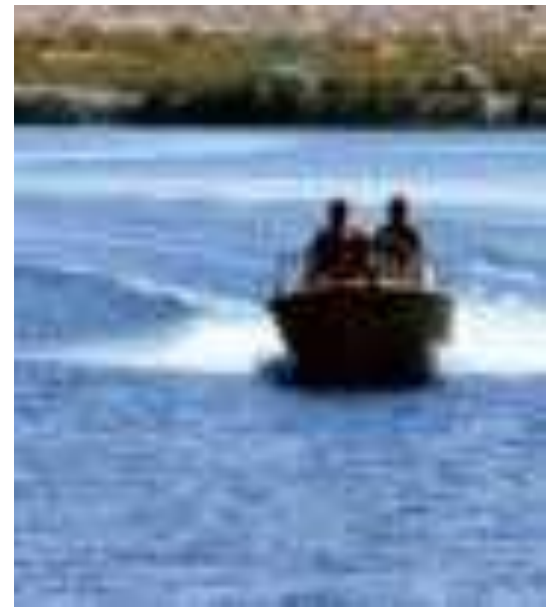

$1(1980)$ three days) and collapse of crater walls prevent any decolonization of fringing vegetation. There is intensive cultivation using water abstracted directly from the crater lakes by a pumping station. The surrounding area is heavily overgrazed by domestic livestock. This gives us warning about the quick destruction of the lake and the big loss of one of the aquatic habitat in Saudi Arabia. Asif-Kan and Al-Homaid (2003) warned from the results of the major disturbance in the coastal regions in Saudi Arabia happened after the Gulf War. They announced that the total loss of the mangrove, in this area, during the past 24 years; from their research; was 259.96 hectares and they give alarm to the necessity of protecting the mangrove and all the aquatic habitats in the area.

For that, the vegetation in Uyun Layla has been studied to recognize the dominant species present and to protect this area from more destruction by the organized use of its resources. During this study fifteen species were recognized they are all perennials, halophytes shrubs namely: Molkiopsis ciliate, Capparis orientalis , Salicornica fruticosa, Zygophyllum coccineum, Zygophyllum simplex, Aeluropus lagopoides, Cressa cretica and Limonium axillare, are common in these karts. While salsola spp., Traganum nudatum, Haloxylon salicornicum and Haloxylon persicum are widely distributed at the bottom of the lakes. Meanwhile Artemisia spp., Zilla spinosa and Ephedra aphylla are found as scattered individuals at the sloping walls of the craters (Photographs 11, 12 \& 13). After two years of this study, at the beginning of 2008, the first three species; Molkiopsis ciliate, Capparis orientalis and Salicornica fruticosa; were scarce and rarely found. These species indicates that Uyun Layla lakes have been transformed to salty habitats and the halophytic vegetation is the only vegetation in this area.

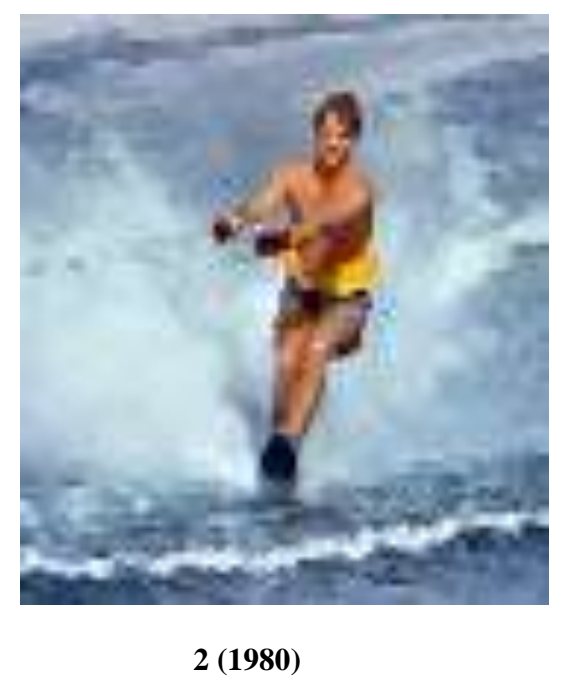




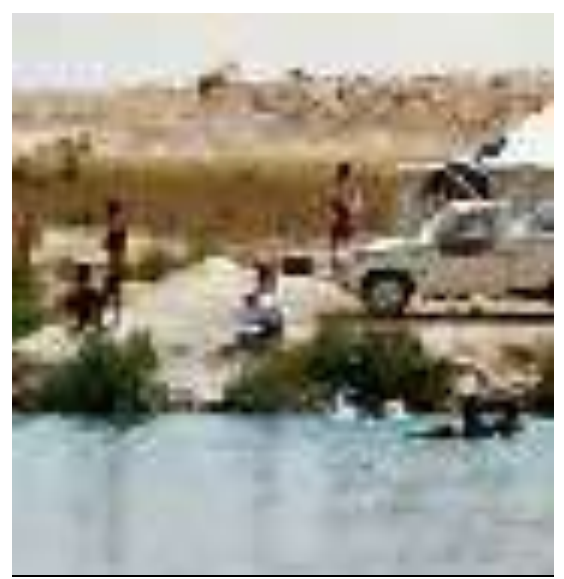

3 (1980)

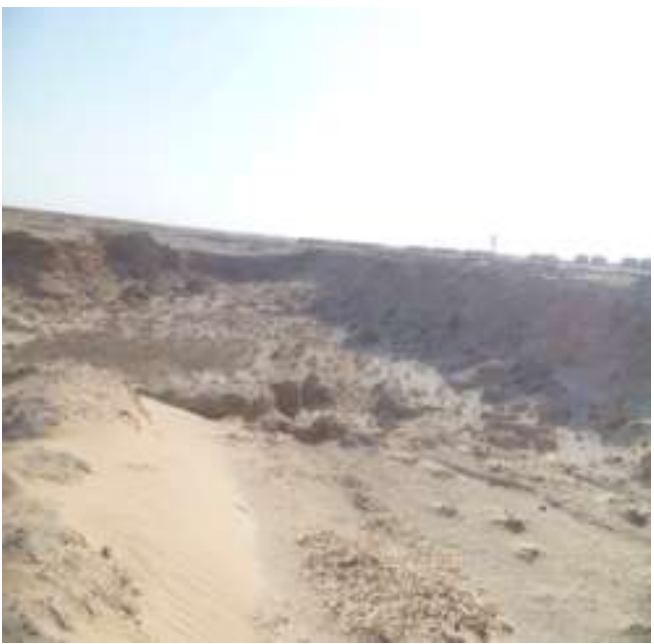

5 (2007)

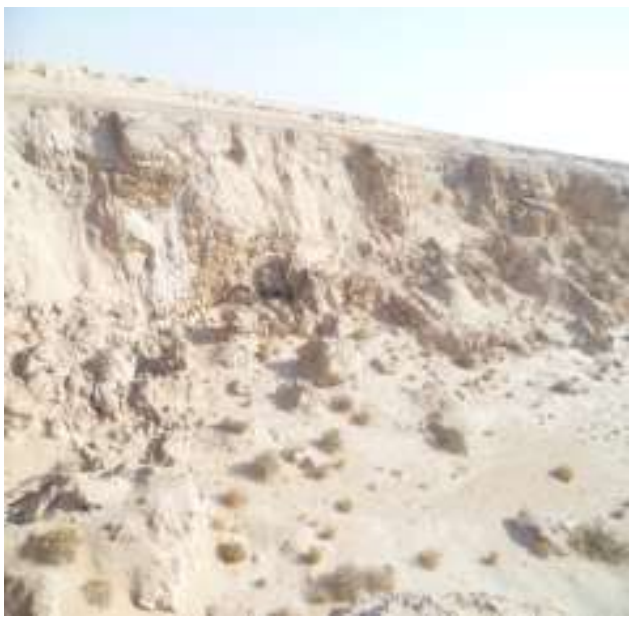

7 (2010)

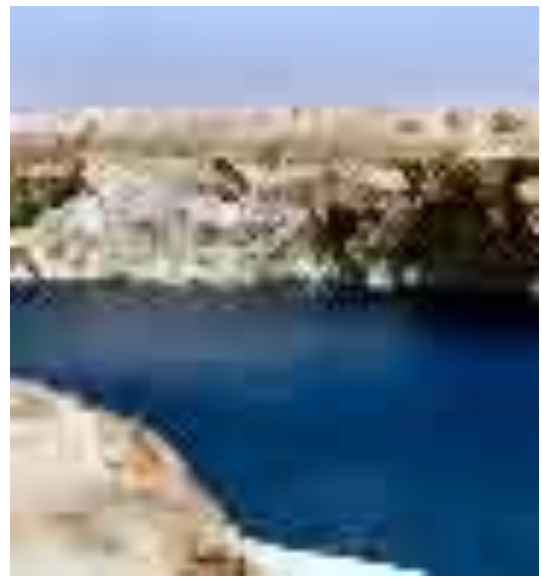

4 (1989)

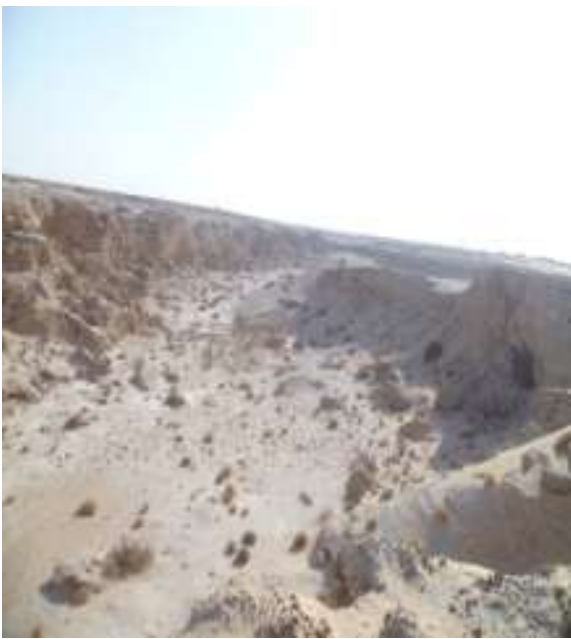

6 (2007)

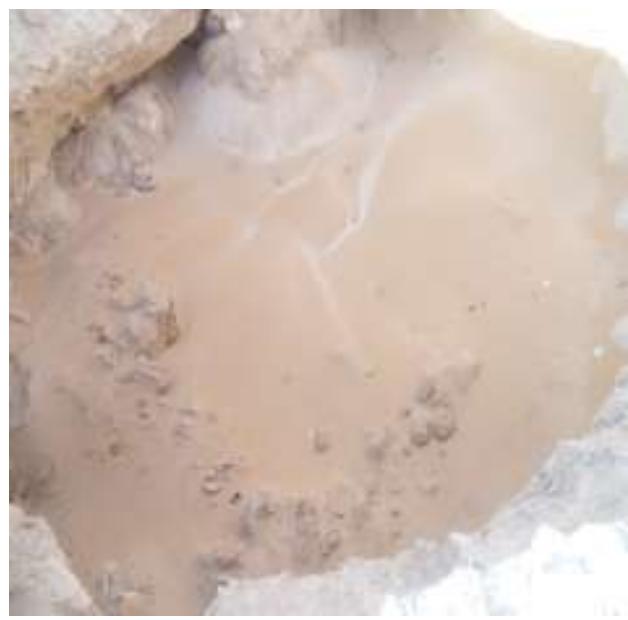

8 (2010) 


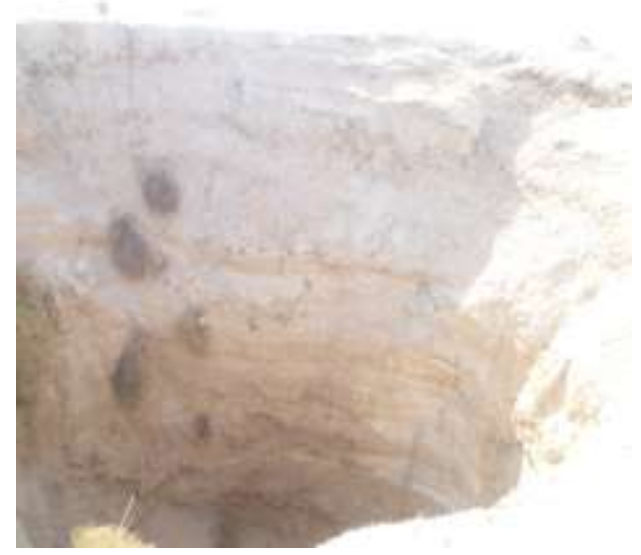

9(2010)

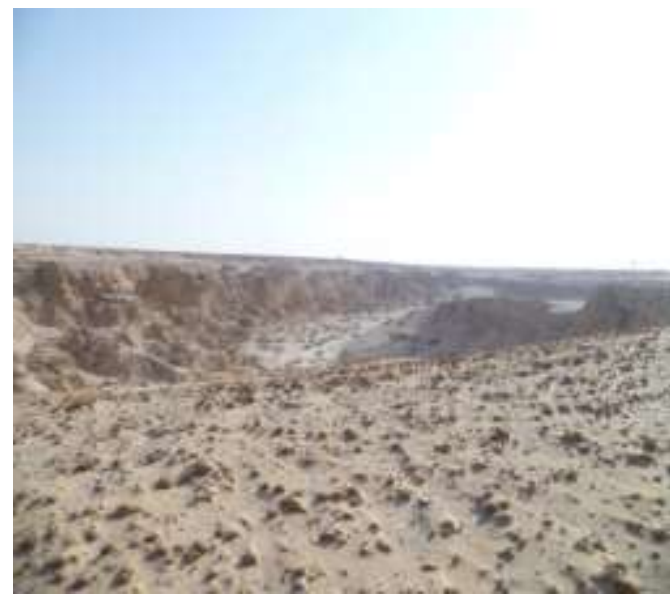

$11(2010)$

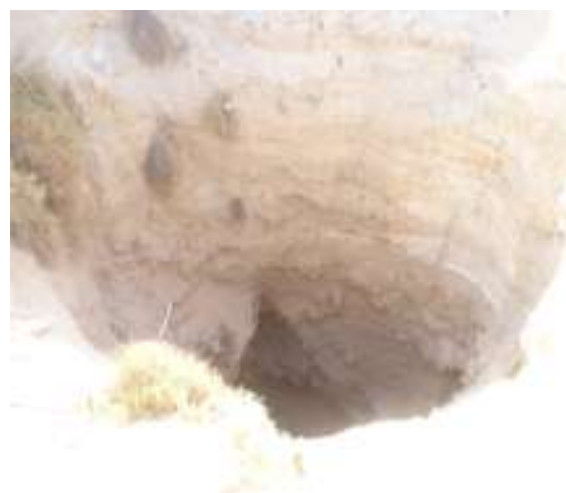

$10(2010)$

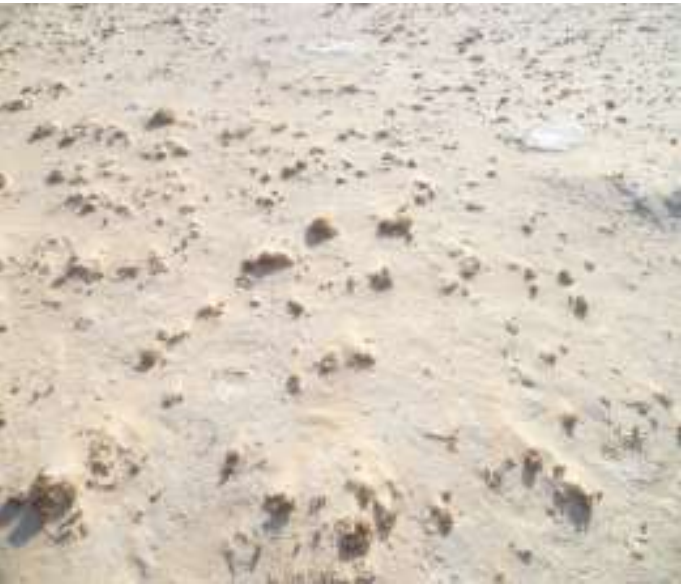

12 (2010)

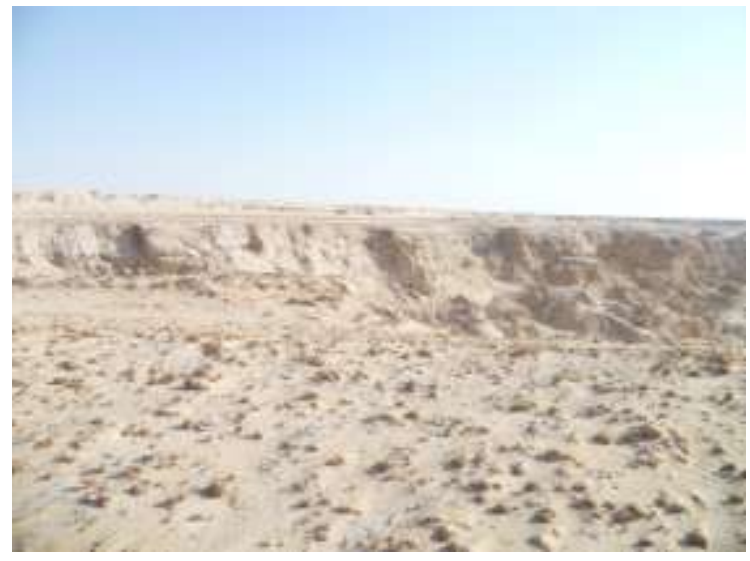

13 (2010)

Fig. 1-6 Photographs submitted by John Paul Jones of http://www.wastausa.com/ showing the disappearance of Uyun Layla 7-12 Recent photographs taken by Al-Ghanem showing the complete disappearance of Uyun Layla and the appearance of the halophytic vegetation $(8 \& 9)$ and sandy soil (7). Photographs 10-12 show the complete desiccation of the crater walls. Photographs 13-14 sow the dry halophytic plants in the karts 
According to this study, the combined effects of habitat destruction and/or fragmentation, environmental contamination and over-exploitation of natural resources have caused irreparable damage to Uyun Laila plant biodiversity. The density of the present vegetation is poor and some taxa are already, in the way to extinct. Meanwhile the rest of the present species are dwarf, dry and seam to be suffering. Lopez-Pujol (2006) had warned of the danger of extinction of 5000 plant species in China due to destruction of habitats and population growth. Brudvig et al.(2009) found that reconnecting landscapes amplifies biodiversity conservation both within and beyond reserve borders.

\section{REFERENCES}

Al-Eizawi, D. (2003). Effect of biodiversity conservation on arid ecosystem with a special emphasis on Bahrain. J. Arid Environ. 54(1):81-90.

Asif-Kan, M. and Al-Homaid, N.A. (2003). Remote Sensing Study on Mangrove Depletion Tarut Bay, Saudi Arabia. In: Desertification in the third Millennium ed. By Alsharhan, A.S.; Wood, W.W.; Goudi, A.S.; Fowler, A. and Abdelatif, E.M. Swets and Zeitiinger, Netherlands .

Barange, M.; Field, J.G.; Harris, R.P.; Eileen, E; Hofmann, E.E.; Perry, R.I. and Werner, F. (2010). Marine Ecosystems and Global Cange. Oxford Univ. Press .

Brudvig, L.A.; Damschen, E.J.; Tewksbury, J.J.; Haddad, N.M. and Levey,D.J.(2009). Landscape Connectivity Promotes Plant Biodiversity spillover into non-Target Habitats. PINAS Pocasts (Proceedings of the Natural Academy of Sciences of the United States of America May 2009).
Davenport, J. (2008). Challenges to Marine Ecosystems: Proceedings of the $41^{\text {st }}$ European Marine Biology Symposium Vol. 202 of Developments in hydrobiology .

Duraiappah,A.K. (2006). Millennium ecosystem assessment: Ecosystems and Human- Well Being- Biodiversity Synthesis. Washington, D.C. World Resources Institute

Johnson, D.L. ;Ambrose, S.H; Bassett, T.J.; Bowen, M.L.;Crummey, D.E.; Isaacson, J.S.; Johnson, D.N.; Lamb, P.; Saul, M. and Winter-Nelson, A.E. (1997).Meanings of environmental terms. J.of Environ. Quality 26: 581-589.

Lopez-Pujol, J.; Zang, F. and Ge, S. (2006). Plant Biodiversity in China: Richly Varied, Endangered, and in Need of Conservation. Biodiversity and Conservation 15 (12): 3983-4026.

Mackey, B. (2007). In Taylor, M., Figgis, P. eds. Protected Areas: buffering nature against climate change. Proceedings of a WWF and IUCN World Commission on protected Areas symposium, Canberra,18-19 June 2007. Sydney:WWF-Australia. Pp.90-96.

Mann, K.. and Lazier,J.R.N. (2006). Dynamics of marine ecosystems: biological-physical interactions in the oceans. Willey-Blackwell .

Pressey, R.L.; Cabeza, M.; Watts, M.E.; Cowling, R.M. and Wilson, K.A. (2007). Review

Conservation planning in a changing world. Trends Ecol. Evol. (Amst.) 22(11): 583-592 .

UNEP/PERSGA, (1997) Assessment of Land-based Sources and Activities Affecting the Marine Environment in the Red Sea and Gulf of Aden. UNEP Regional Seas Report and Studies No. 166 . 
120

ALEXANDRIA SCIENCE EXCHANGE JOURNAL, VOL. 31, No. 2 APRIL-JUNE 2011

الملخص العربي

دراسة بيئية علي عيون ليلي بالمملكة العربية السعودية

وفاء تُمَّمَ الغانم

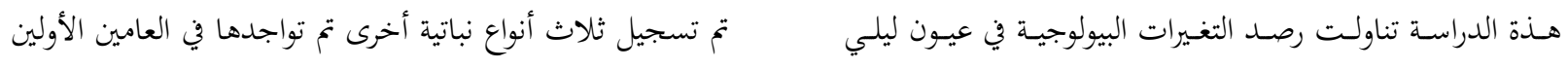

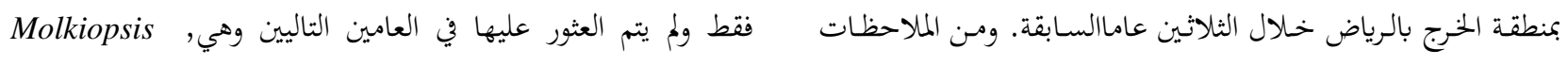
, ciliate, Capparis orientalis \& Salicornica fruticosa

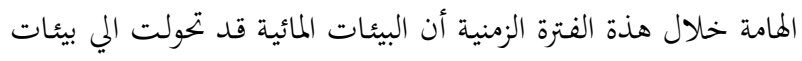

يدل علي تغير البيئة الملائمة لمم بهذة المواقع. أرضية جافة مع تغير واضح في أنواع النباتات النامية بها.

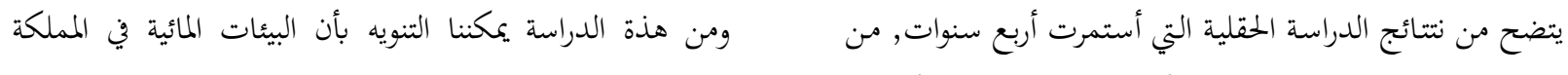

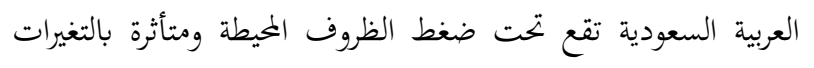

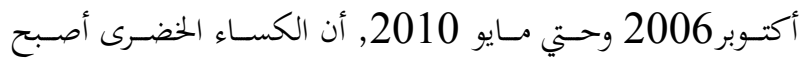

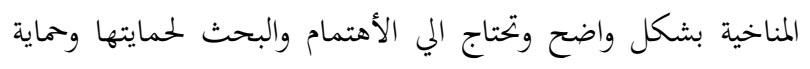

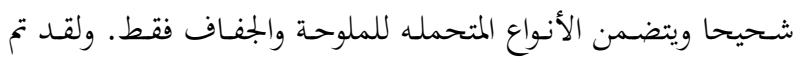
الأنواع النباتية النامية بما.

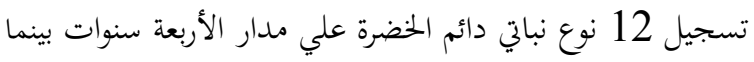

